
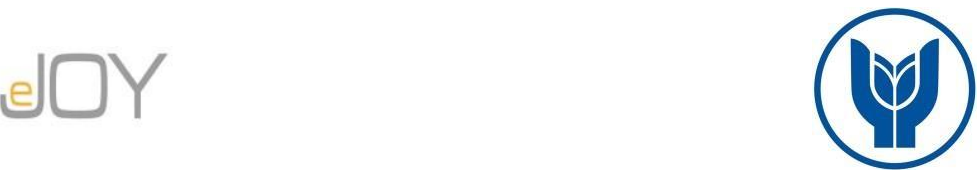

Özdemir, B., Şahin, A. / Journal of Yasar University, 2021, 16/63, 1256-1281

\title{
Kişisel Değerlerin Restoran Seçimine Etkisi: Dışarıda Yemek Yeme Motivasyonlarının Aracılık Rolü
}

\section{The Effects of Personal Values on Restaurant Choice: The Mediating Role of Eating Out Motivations}

\author{
Bahattin ÖZDEMİR, Akdeniz Üniversitesi, Türkiye, bahattin@akdeniz.edu.tr \\ Orcid No: 0000-0002-6615-0023 \\ Ayşe ŞAHİN, Akdeniz Üniversitesi, Türkiye, asahin@akdeniz.edu.tr \\ Orcid No: 0000-0001-8533-7187
}

\begin{abstract}
Öz: Bu araştırmanın amacı kişisel değerler, dışarıda yemek yeme motivasyonları ve restoran seçimi arasındaki ilişkileri incelemektir. Ilgili literatürden yararlanılarak dört hipotez belirlenmiştir. Bunlardan ikisi kişisel değerlerin motivasyonlar ve restoran seçimi üzerindeki etkisi; diğer ikisi ise motivasyonların restoran seçimine etkisi ile kişisel değerler ve restoran seçimindeki aracılık rolüyle ilgilidir. Çevrimiçi olarak yürütülen veri toplama safhasında 398 kişiye ulaşılmış ve uç değerler nedeniyle elenen anket formlarından dolayı 391 adet katılımcının yanıtı değerlendirmeye alınmıştır. Doğrulayıcı faktör analizi ile ölçüm modelinin uygunluğu değerlendirildikten sonra araştırma modeli kapsamında oluşturulan hipotezler yapısal eşitlik modeli ile test edilmiştir. Hipotezlerin tamamı araştırma bulgularından destek bulmuştur. Bulgular ışı̆̆ında kişisel değerlerin restoran seçimi ve dışarıda yemek yeme motivasyonlarını etkileyen bir faktör olduğu ve dişarıda yemek yeme motivasyonlarının restoran seçimini etkilediği gibi değerler ve restoran seçimi arasında aracılık rolü üstlendiği saptanmıştır. Bulgular ve ilgili literatür ışığında kişisel değerlerin restoran seçiminin koşul bă̆ımlılık özelliğini azaltan bir değişken olabileceği görüşü tartışılmıştır.
\end{abstract}

Anahtar Kelimeler: Kişisel Değerler, Restoran Seçimi, Dışarıda Yemek Yeme Motivasyonlar.

JEL Siniflandirmast: L66, L83, M31

Abstract: This study aims to examine the effect of personal values on eating out motivations and restaurant choice. Relying on the prior researches, the relationship between personal values, eating out motivations and restaurant choice was discussed and questionnaires were administered to 398 participants in this study. After the elimination of questionnaires that contained extreme values, 391 questionnaires were analyzed. Firstly, confirmatory factor analysis was conducted to evaluate the measurement model. Secondly, the hypotheses of the research were tested using structural equation modeling. All of the hypotheses were supported by the research findings. Results show that personal values are an important antecedent on restaurant choice. The findings of the study also imply that eating out motivations have a partial mediating role in the relationship between personal values and restaurant choice.

Keywords: Personal Values, Restaurant Choice, Eating Out Motivations

JEL Classification: L66, L83, M31

\section{Giriş}

İlgili literatürde restoran seçimi restoranlar bağlamındaki önemli tüketici davranışlarından biri olarak görülmekte, bu yüzden birçok araştırmaya konu edilmekte ve tüketicilerin restoran niteliklerine verdiği öneme göre gerçekleştiği kabul edilmektedir (Özdemir, 2018). Yine aynı literatür restoran niteliklerine atfedilen önemin tüketicinin sosyo-demografik özellikleri, dışarıda yemek yeme motivasyonu, gideceği restoran türü, yemek zamanı ve yemeğin kiminle yenileceği gibi faktörlere bağlı olarak bireye, zamana ve mekâna göre değişkenlik gösterdiğini 
söylemektedir (Auty, 1992; Y1lmaz ve Gültekin, 2016; Kim ve Geistfeld, 2003). Buna göre restoran seçimi dinamiktir ve koşul bağımlılık özelliği gösterir.

Tüketicilerin restoranlardaki yiyecek tüketimleri doğrusal bir süreç olarak ele alınırsa dışarıda yemek yeme motivasyonları ile başladığı restoran ve yemek seçimi, yemek deneyimi, memnuniyet ve davranışsal niyetler şeklinde ilerlediği söylenebilir (Wijaya vd. 2013). Motivasyonlar sürecin ilk aşaması olması nedeniyle nerede yeneceği, ne yeneceği, kiminle yeneceği, ne kadar süre ile yeneceği ve yemekten ne kadar memnun olunacağı gibi soruların yanıtları için ilk başvuru yapılan kaynak olmaktadır. Bu yüzden dışarıda yemek yeme motivasyonlarının neler olduğu ve nelerden etkilendiği birçok araştırmacı açısından dikkate değer bir araştırma sorusu olmuştur (Kwun vd. 2013; Ertürk, 2018; Nişancı vd. 2018). Bu bağlamda motivasyonların bireye ve zamana göre yaşanan değişmelerin restoran seçimlerini koşul bağımlı hale getiren başlıca faktörlerden biri olduğu söylenmektedir (Ponnam ve Balaji, 2014). Oysa literatürde çok fazla çalışmada yer almayan 'kişisel değerler' hem motivasyonların hem de restoran seçiminin öncüllerinden biri olarak görülürse 'restoran seçimlerinin ne kadar koşul bağımlı olduğu' yönünde bir tartışma başlatmak olanaklı olabilir. Çünkü kişisel değerlerin tüketimle ilgili olanlar da dahil olmak üzere bireylerin davranışlarını etkilediği (Chryssohoidis ve Krystallis, 2005), ancak sosyo-kültürel kaynaklı olmaları (Karalar ve Kiracı, 2010) nedeniyle belirli bir tüketim öncesinde de var oldukları kabul edilmektedir. Yani kişisel değerler sosyalleşme sürecinin farklılığg nedeniyle bireyden bireye değişebilse de zaman içinde çok az değişim gösterdikleri söylenebilir. Böylece kişisel değerlerin etkisi ile şekillenen davranışların zaman içinde tutarlılık göstermesi beklenmektedir. Söz konusu tutarlılık restoranlar bağlamında tüketicilerin dışarıda yemek yeme motivasyonları ve restoran seçimleri için de gerçekleşebilir ve bu da restoran seçimlerinin koşul bağımlılık özelliğini azaltan bir etki yaratabilir.

$\mathrm{Bu}$ çalışma ilgili literatürdeki araştırmaların modellerinde olduğu gibi koşul bağımlığa yol açan değişkenlerle (sosyo-demografik özellikler, restoran türü, dışarıda yemek yeme motivasyonları) sınırlı kalarak restoran seçiminin neredeyse tamamen koşul bağımlı olduğunu söylemenin eksik bir bakış açısı olacağını kabul etmektedir. Bu nedenle mevcut çalışmada 'kişisel değerler' gibi koşul bağımlılığın etkisini nispeten de olsa azaltabilen bir değişkenin motivasyonlar ve restoran seçimi ile bağlantısını incelemenin bu eksikliği gidermede yararlı olabileceği ileri sürülmektedir. Bu bağlamda çalışmada tüketici davranışlarını anlamada etkili olduğu düşünülen kişisel değerlerin dışarıda yemek yeme motivasyonları ile restoran seçimi üzerindeki etkisinin sınanması amaçlanmaktadır. Bununla birlikte, çalışma ile motivasyonların kişisel değerler ile restoran seçimi arasındaki ilişkisine aracılık edip etmediğine ilişkin bir 
inceleme yapmak da amaçlanmaktadır. Söz konusu ilişkilerin varlığının gösterilmesi ile kişisel değerlerin restoran seçiminin koşul bağımlılığı açısından nasıl bir rol oynadığına ilişkin bir tartışma açmak olanaklı olacaktır.

\section{Kavramsal Çerçeve}

\subsection{Kişisel Değerler}

Değer, kültür ile şekillenen (Kim vd. 2002), bireylerin kararlarını ve eylemlerini yönlendiren ve bireysel kimlik ve yaşam tarzıyla ilişkilendirilen bir olgu olarak görülmektedir (Vinson vd. 1977). Üstelik değerin bireyin tutumlarının oluşmasında önemli bir rol oynadığı kabul edilmektedir. Kısaca değer, bireysel tutum ve davranışları şekillendirmektedir (Chryssohoidis ve Krystallis, 2005). Çünkü, Vinson ve arkadaşlarının (1977) da vurguladığı gibi kişilere, nesnelere veya fikirlere ilişkin değerlendirmede ya da seçimlerde bireyin sahip olduğu değerlerin yani kişisel değerlerin etkisi her zaman hissedilmektedir. Kişisel değerler, bireyin içinde yetiştiği veya yaşadığı toplumsal kültürle bağlantılıdır (Kim vd. 2002), çünkü büyük oranda bireyin sosyalleşme sürecinde oluşurlar (Karalar ve Kiracı, 2010). Bu görüşe göre kişisel değerler sosyal ilişkiler geliştirme, kültürel değerleri özümseme ve bireysel deneyimlerden öğrenme yoluyla elde edilir, kimliğe ve yaşam tarzına bağlı olarak geliştirilir veya değiştirilebilir. Bu sebeple farklı kültürdeki insanların davranışlarını anlamak için değerlerin kullanılması şaşırtıcı değildir (Lee vd. 2014).

Bireylerin davranışlarındaki etkisi nedeni ile kişisel değerleri tanımlamak için çeşitli sınıflandırmalar yapılmıştır. Bunlardan biri de Schwartz'ın (1992) değer teorisidir. Schwartz'a (1992) göre 10 farklı kişisel değer bulunmaktadır ve bunlar güvenlik (ulusal güvenlik, toplumsal düzen, temiz olma), hedonizm (keyif, yaşamdan zevk alma), iyilikseverlik (yardımseverlik, dürüstlük, bağışlayıcı olma), öz yönelim (yaratıcılık, merak, özgünlük), uyarılım (cesaret, yaşamda çeşitlilik), evrenselcilik (geniş fikirlilik, sosyal adalet, eşitlik, çevreyi koruma), geleneksellik (alçakgönüllülük, dindarlık, hayatın sunduklarını kabul etme), uygunluk (nezaket, itaatkarlık, aileyi ve yaşlıları şereflendirme), başarı (yetenek, hırs) ve güç (sosyal güç, otorite, zenginlik) şeklinde sıralanmaktadır. Aynı zamanda bu değerler yeniliğe açıklık (öz yönelim, uyarılım ve hazcılık), tutuculuk (güvenlik, uygunluk ve geleneksellik), özaşkınlık (evrenselcilik ve iyilikseverlik) ve özgenişletim (güç ve başarı) olarak dört boyut ile de kavramsallaştırılabilmektedir.

Değer, tüketici davranışlarını anlamak için gerçekleştirilen araştırmalarda da önemli bir değişken olarak yer almaktadır (Korkmaz Devrani, 2010). Aslında tüketici davranışları açısından değer kavramı 'algılanan değer' ve 'kişisel değerler' olmak üzere iki ana kategoride 
düşünülebilir. Zeithaml (1988) algılanan değeri, tüketim kapsamında 'ne alındı̆̆ l (fayda) ve karşılı̆̆ında ne verildiğine (fedakârlık, maliyet) ilişkin öznel dĕgerlendirme’ şeklinde tanımlamıştır. Buna göre tüketicilerin değer algılaması tüketimden elde edilen faydaya göre değişir (Huber vd. 2001). Aslında algılanan değerin bireyden bireye (sosyo-demografik özellikler, eğilimler, tutum vb. nedeniyle) değişmesi kadar tüketim anındaki koşullara (fiyat, atmosfer, kalite algılaması vb.) bağlı olarak da değişkenlik göstermesi olasıdır (Sweeney ve Soutar, 2001). Öyleyse tüketim kaynaklı olan algılanan değerin belirli bir zaman ve mekânda yaşanan tüketici deneyimlerine bağlı olarak nispeten kısa sürelerde etkisini gösteren ve tüketimden tüketime değişen bir olgu olduğu söylenebilir. Buna karşın kişisel değer ise içine doğulan veya içinde yaşanılan kültür ve tercih edilen yaşam tarzından kaynaklanması nedeniyle bireyin yaşamının daha geniş bir döneminde varlığını sürdürür ve kısa sürede değişmesi beklenmez (Vinson vd. 1977; Lee vd. 2014). Dolayısıyla tüketici davranışları açısından ele alındığında algılanan değer tüketim kaynaklı olduğundan koşul bağımlıdır. Kişisel değerlerin ise sosyo-kültürel kaynaklı olduğu için bireyden bireye değişse de tüketimle ilişkilendirildiğinde koşul bağımlı olmadığı, yani tüketimden tüketime değişmediği söylenebilir.

İlgili literatürde tüketicilerin restoranlar bağlamındaki yemek deneyimlerindeki rolü açısından kişisel değerlerden çok algılanan değerin incelendiği görülmektedir. Söz gelimi Kim vd. (2011) çevreye duyarlı tüketici davranışları bağlamında algılanan değerin tüketicilerin restoranlardaki sağlıklı yiyeceklere ilişkin kalite algılamasını ve tekrar ziyaret etme niyetini etkilediğini saptamıştır. Dahası restoranlardaki araştırmalarda algılan değerin hedonik ve faydacı değer olarak iki boyutta incelendiği de gözlemlenmektedir. Örneğin Ryu vd. (2010) hedonik ve faydacı değerlerin restoranlarda hem müşteri memnuniyetini hem de davranışsal niyeti etkilediğini belirlemiştir. Kişisel değerlerin ise daha çok organik yiyecek (Dreezens vd. 2005) ve sağlıklı yiyecek (Lee vd. 2014) satın alımı gibi restoran dışı bağlamlardaki yiyecek tüketim davranışlarıyla ilişkisinin ele alındığı görülmektedir. Kişisel değerlerin etkisi üzerine bu ve benzeri araştırmalar 'tüketicilerin kendi kişisel değerlerine uyan ürünleri tercih etme eğiliminde oldukları' yönündeki görüşü benimsemektedir (Karalar ve Kirac1, 2010). Buna göre kişisel değerler tüketiciyi seçim yapması için harekete geçirmekte ve satın alma niyeti, sadakat ve daha fazla ödemeye isteklilik gibi davranışsal niyetleri etkilemektedir (Kim vd. 2019). Bu bağlamda Schwartz'ın (1992) değer teorisi de tüketim araştırmalarında kullanılmaktadır. Söz gelimi, Karalar ve Kiracı (2010) Schwartz'ın (1992) oluşturduğu kişisel değerlerden evrenselcilik ve güvenlik değerlerinin sürdürülebilir tüketim davranışı üzerinde pozitif bir etkiye sahip olduğunu belirlemiştir. 
Kişisel değerlerin benzer etkileri restoranlar bağlamında da gözlemlenebilir ve motivasyonlar, enformasyon arayışı, seçimler (restoran ve yemek), deneyimden memnuniyet ve davranışsal niyetler gibi belli başlı tüketici davranışlarını etkileyebilir. Bu yönüyle kişisel değerler restoranlarda yapılan tüketici araştırmalarında dikkate alınması gereken bir değişken olmaktadır. Üstelik kişisel değer algılanan değerden farklı olarak doğrudan belli bir tüketimden kaynaklanmaması, yani algılanan değere kıyasla koşul bağımlılığa yol açma olasılığı daha düşük olması nedeniyle özellikle dışarıda yemek yeme motivasyonları ve restoran seçimleri üzerindeki etkisi açısından incelemeye değer bir değişken olarak görülebilir.

\subsection{Dışarıda Yemek Yeme Motivasyonları}

Dışarıda yemek yeme basitçe 'tüketicilerin bir restoran işletmesi tarafindan hazırlanan ve servis edilen yiyecek ve içecekleri ücretini ödeyerek ev dışında tüketmesi' şeklinde tanımlanabilir (Özdemir, 2010). Dolayısıyla tüketicilerin neden kendi evlerinde değil de dışarıda yemek yedikleri çok önemli bir soru olmaktadır. İlgili literatüre göre bu sorunun yanıtı zaman zaman dışarıda yemek amaçları veya nedenleri şeklinde de adlandırılan 'dışarıda yemek yeme motivasyonu' ile verilebilir. Çünkü araştırmacılara göre (Auty, 1992; Kivela, 1997; Ali ve Nath, 2013; Ponnam ve Balaji, 2014; Nişancı vd. 2018) bir tüketicinin nerede yemek yiyeceği, ne yiyeceği, kiminle yiyeceği, ne kadar süre ile yiyeceği ve yemekten ne kadar memnun olacağı motivasyonlarına göre şekillenebilmektedir.

Öneminin anlaşılmasıyla doğru orantılı olarak ilgili literatürde tüketicilerin dışarıda yemek yeme motivasyonlarını keşfetmeye yönelik dikkate değer sayıda akademik çalışmanın yapılmış olduğu görülmektedir. Bunlara göre tüketicileri dışarıda yemek yemeye iten çok sayıda ve farklı motivasyon faktörü olduğuna inanılmaktadır. Söz gelimi, Kivela (1997) bunları kutlama, iş amaçlı, sosyal amaçlı ve kolaylık olarak sıralarken; Narine ve Badrie (2007) özel günler, arkadaşlarla bir araya gelme, keyif, uygunluk, tat/lezzet şeklinde sıralamaktadır. Ali ve Nath (2013) ise tüketicilerin en çok özel günler için dışarıda yemek yemeyi tercih ettiklerini ileri sürmektedir. Dışarıda yemek yeme motivasyonları ulusal yazındaki çalışmalara da konu edilmektedir. Bunlardan birinde Albayrak (2014) tüketicilerin dışarıda yemek yeme nedenlerini sırasıyla ‘aile/arkadaşlarla birlikte olma, kutlama gibi özel nedenler ve ekonomik olma' olarak saptamıştır. Benzer şekilde Nişancı vd. (2018) dışarıda yemek yeme nedenlerinin başında 'aile ve arkadaşlarla vakit geçirmek' olduğunu ifade etmektedir.

Tek tek sıralamak yerine bazı araştırmacıların çok sayıdaki motivasyon faktörünü gruplayarak ele aldığı görülmektedir. Söz gelimi Özdemir (2010) ve Bekar ve Dönmez (2016) söz konusu motivasyonları fizyolojik, psikolojik, ekonomik ve sosyal boyutlar altında 
toplamaktadır. Öte yandan dışarıda yemek yeme motivasyonları turist davranışı ile ilgili literatürde yapıldığı gibi iten ve çeken faktörler (Crompton, 1979) şeklinde de gruplandırılabilir. İten faktörler bireyin içinde bulunduğu çevrede var olan sosyal ilişkiler ve koşullardan kaynaklanır ve bireyin çevresinden uzaklaşma isteği duymasına yol açar. Kim ve diğerleri (2003) iten motivasyon faktörlerini aile ve arkadaşlarla birlikte olma, öğrenme, doğayı keşfetme, sağlıklı olma, günlük rutinden uzaklaşma, maceraya atılma vb. isteği şseklinde sıralamaktadır. Çeken faktörler ise bir turizm destinasyonunun turistleri oraya seyahat etmeye isteklendiren çekicilikleri şeklinde tanımlanmaktadır. Yine Kim ve diğerleri (2003) çeken faktörler için destinasyonun kültürel ve tarihi değerleri, doğal güzellikleri, enformasyon kaynakları, turizm tesisleri, erişilebilirlik ve ulaşım kolaylığı şeklinde örneklendirmektedir. Dışarıda yemek yeme motivasyonları açısından Akova vd. (2017) benzer bir ayrımı içsel (sosyalleşme, statü, kendini gerçekleştirme, mutluluk, eğlence vb.) ve dişsal (güvenlik, çeşitlilik, ucuzluk vb.) faktörler kavramsallaştırması ile yapmıştır. Dolayısıyla restoranlar açısından da tüketicilerin kendi evlerinde değil de bir restoranda yemek tüketmelerine neden olan iten (sosyalleşme, öğrenme, sağlıklı olma, mutlu olma, rutinden uzaklaşma vb.) ve çeken (restoranın yiyecek kalitesi, manzarası, yenilikçi tarzı, imajı vb.) motivasyon faktörleri olduğu söylenebilir.

Tüketicilerin dışarıda yemek yeme motivasyonları çeşitlilik gösterebildiği gibi bireye ve zamana göre de değişkenlik gösterebilir. Buna göre tüketicilerin sosyo-demografik özellikleri (Bekar ve Dönmez, 2016; Ertürk, 2018), hedonik veya yararcı şeklindeki tüketim değerleri (Park, 2004), yiyecek konusundaki çeşitlilik arayışları (Kwun vd. 2013) ve yiyecekle ilgilenimleri (Beldona vd. 2010) motivasyonlarını etkilemektedir. Üstelik motivasyonların tüketicilerin restoran seçimlerini etkilediği (Auty, 1992; Kivela, 1997; Ponnam ve Balaji, 2014) düşünüldüğünde motivasyonlardaki değişkenliğe bağlı olarak restoran seçimlerinin de bireye ve zamana göre değişim gösterebileceği akla gelmektedir. Ancak motivasyonların en azından zamana göre değişkenliğini azaltan bir faktörün varlığı söz konusu olursa restoran seçiminin değişkenliği ve dolayısıyla koşul bağımlılığı tartışmaya açılabilir. Bu konuda kişisel değerlerin etkisi sinanmaya değer görülmektedir.

\subsection{Restoran Seçimi}

Restoranlar yiyecek kalitesi ve çeşitliliği, atmosfer, hizmet kalitesi, konum, fiyat vb. çok sayıda niteliğe sahiptir ve bunlar üzerinden tüketicilere fayda yaratmaktadır. Restoran seçimi de tüketicilerin elde edeceği faydaya göre restoranların sunduğu nitelikleri değerlendirmesiyle gerçekleşmektedir (Özdemir, 2018). Restoran seçimi üzerine akademik çalışmalar da bu görüş 
etrafında şekillenmekte ve ilgili çalışmalarda tüketicilerin restoran seçerken hangi restoran niteliklerini dikkate aldığı ve bu niteliklere ne kadar önem verdiği ölçülmektedir. Dolayısıyla restoran seçimi ile ilgili araştırmalarda ilk göze çarpan bulgular tüketicilerin restoran seçiminde önemsedikleri niteliklerin sıralamasıdır. Çalışmadan çalışmaya niteliklerin sırasında zaman zaman değişme görülse de konu ile ilgili erken dönemli çalışmalarda (Auty, 1992; Kivela, 1997) restoran seçiminde etkili olabilecek nitelikler araştırmaya katılanların atfettikleri önem düzeyine göre yemek kalitesi, menü çeşitliliği, fiyat, atmosfer, servis hızı ve konum şeklinde sıralanmaktadır. Nispeten yakın zamanda yapılan bir araştırmaya (Medeiros ve Salay, 2013) göre de erken dönemdeki çalışmaların bulgularına benzer şekilde tüketicilerin restoran seçerken en çok önem verdikleri nitelikler yiyecek kalitesi, fiyat, atmosfer ve konum şeklinde belirlenmiştir. Bununla birlikte, son yıllardaki çalışmalar erken dönemli çalışmalarda ele alınan ve geleneksel restoran nitelikleri şeklinde isimlendirilebilecek niteliklerin yanı sıra sağlıklı yiyecek sunumu (Choi ve Zhao, 2010); çevreye duyarlılık (Jang vd. 2011) ve yerel yiyecek kullanımı (Alonso vd. 2013) gibi niteliklerin de restoran seçiminde etkili olabileceğini işaret etmektedir.

İlgili literatürdeki çalışmalar tüketicilerin restoran seçerken önemsediği niteliklere göre sıralamalar önerse de söz konusu niteliklerin sıralamasında değişkenlik olabileceğini göz ard1 etmemektedir. Örneğin, Y1lmaz ve Gültekin'e (2016) göre sosyo-demografik özellikler, dışarıda yemek yeme motivasyonları, restoranın türü ve kiminle yemek yenileceği gibi değişkenler restoran seçimini etkilemektedir. Harrington vd. (2011) ve Harrington vd. (2013) ise cinsiyet ve yaş gibi demografik değişkenlerin yanı sıra dışarıda yemek yeme sıklığının da hem lüks restoranlar hem hızlı servis sunan restoranlar bağlamında restoran seçiminde etkili olabileceğini ileri sürmektedir. Auty (1992) ve Kivela (1997) ise sosyo-demografik özellikler, dışarıda yemek motivasyonu ve restoran türünün restoran seçiminde değişkenliğe yol açabileceğini ampirik bulgularla ortaya koymuştur. Dolayısıyla ilgili literatüre göre restoran seçiminde önemsenen niteliklerin sıralaması bireye, zamana ve mekâna göre değişmekte ve böylece restoran seçimi koşul bağımlılık özelliği göstermektedir.

$\mathrm{Bu}$ görüş 'uyarılmış set' kavramsallaştırması ile bir adım ileri taşınmaktadır, çünkü motivasyonların nihai olarak restoran seçiminin içinden yapıldığı uyarılmış seti belirlemede etkili olduğu düşünülmektedir (Cullen, 2004). Bu konuda Auty (1992) ve Kivela'nın (1997) çalışmaları öncü olmuştur. Araştırmacılara göre dışarıda yemek yeme motivasyonu restoran seçiminin ilk aşamasında belirleyicidir. Böylece dışarıda yemek yeme motivasyonuna göre restoran seçimde önemsenen niteliklerin ilk sıralaması belirlenmektedir. Bu sıralamaya göre yemek kalitesi, yemek çeşitliliği ve fiyat en çok önemsenenler olarak çok sayıda alternatif 
restoran arasında bir eleme yapmada kullanılmaktadır. Bu eleme sonucu yemek kalitesi, yemek çeşitliliği ve fiyata göre birbirine denk olabilecek birkaç restoran seçeneğinden (çoğunlukla dört veya beş restoran gibi) oluşan bir restoran seti ortaya çıkmaktadır. Buna da 'daraltılmış set' veya 'uyarılmış set' adı verilmektedir (Arıker, 2012). Tüketici nihai seçimini uyarılmış set içerisinde yer alan restoranlar arasından yapmaktadır. Uyarılmış setten yapılan seçimde ise ilk aşamadaki seçimde veya elemede daha az önemli olabilen atmosfer ve tarz gibi başka nitelikler belirleyici olabilmektedir. Dolayısıyla restoranlar arası rekabet aslında büyük oranda uyarılmış set içerisinde yer alan restoranlar arasında ve tüketicinin nihai seçimini belirleyen faktörler üzerinden gerçekleşmektedir.

Yine ilgili literatürde restoran seçiminin koşul bağımlılık özelliğini gösterdiğini işaret edebilecek bir başka kuramsal yaklaşım da ‘ödünleşim' olarak görülebilir. Buna göre tüketiciler restoran seçimi sırasında sahip olduğu beklentiler (kalite, fiyat, hız vb.) ve kaynaklar (zaman, emek, para vb.) için birbiriyle yarışan nitelikler (yiyecek kalitesi, servis kalitesi veya fiyat gibi) arasında birini veya birkaçını diğerlerinden daha çok önemseyebilir. Aslında bunu yaparken bir nitelik uğruna diğerinden vazgeçmektedirler (Koo vd. 1999). Diğer bir deyişle, tüketici için restoran nitelikleri arasında atfedilen öneme göre bir tercihte bulunmak bazı niteliklerden ödün vermek anlamına gelmektedir. Bu konuda ampirik kanıt Jung vd. (2015) tarafindan yapılan bir araştırma ile sunulmaktadır. Araştırmaya göre yemek kalitesi en önemli niteliktir. Buna ilaveten, tüketiciler bir restoranın yemek kalitesi iyi değilse servis kalitesi yüksek ve fiyatı düşük olsa dahi bu restoranı seçmeme eğilimi sergilemektedir. Bir bakıma tüketiciler yemek kalitesi için servis kalitesi ve fiyattan ödün verebilmektedir. Bir başka ifade ile yemek kalitesi restoran seçiminde ödün verilmeyecek nitelik olmaktadır. Uyarılmış set ve ödünleşim şeklindeki kuramsal yaklaşımlar araştırmacıları restoran seçimlerinin koşul bağımlı olduğuna ilişkin bir görüşe ikna etmiş gibi görünse de kişisel değerlerin etkisi ile hem uyarılmış set içinde hem de ödünleşim bağlamında restoran seçiminin değişkenliğinin azalıp azalmayacağının tartışılması yararlı olacaktır.

\subsection{Araştırma Modeli ve Hipotezler}

Daha önce de belirtildiği gibi tüketici davranışı ile ilgili araştırmalar bir ürünün tüketiminin kişisel değerler yoluyla şekillenebileceğini söylemektedir (Huber vd., 2001). Çünkü, tüketicilerin kişisel değerleriyle uyum gösteren ürünleri tercih ettiği bilinmektedir. Öte yandan restoranlar bağlamında çok incelenmese de kişisel değerlerin yiyecek tüketiminde önemli bir role sahip olduğu görülmektedir. Söz gelimi, Dreezens vd. (2005) araştırmalarında Schwartz'ın (1992) oluşturduğu kişisel değerlerden evrenselcilik değerinin organik yiyecek satın alma 
kararında pozitif bir etkiye sahip olduğunu saptamıştır. Lee vd. (2014) ise Schwartz'ın (1992) belirlediği kişisel değerlerden güvenlik, hedonizm, yardımseverlik ve öz yönelim değerlerine sahip kişilerin sağl1klı yiyecek ve içecek tüketimine daha çok önem verdiğini belirtmektedir.

Kişisel değerlerin bireylerin yaşam tarzıyla doğrudan bağlantılı olduğu bilinmektedir (Korkmaz Devrani, 2010). Bir bireyin ya da grubun düşünüş, algılayış ve davranış özelliği olarak tanımlanan yaşam tarzı (Lee vd., 2014) akademik çalışmalarda motivasyon, seçim, memnuniyet ve davranışsal niyetler gibi çeşitli tüketici davranışlarını anlamak için sıklıkla kullanılmaktadır (Kesic ve Piri-Rajh, 2003). Bu bağlamda yaşam tarzının bileşenlerinden biri olan kişisel değerlerin tüketim motivasyonlarını etkilediği ileri sürülebilir (Gómez-Corona ve Valentin, 2019). Ayrıca, yiyecek tüketim örüntüleri (ne yendiği, nerede yendiği, kiminle yendiği vb.) de bireylerin kişisel kimlikleri ve yaşam tarzlarının başlıca göstergelerinden biridir (Van Huy vd. 2019). Dolayısıyla yaşam tarzı ve yiyecek tüketim davranışlarının örtüştüğü yerde kişisel değerlerin bir rolü olduğunu düşünmek doğaldır. Bu görüşü destekler şekilde Hansen vd. (2018) Schwartz'1n (1992) belirlediği kişisel değerlerin organik yiyecek tüketme motivasyonları ile organik yiyecek tüketme davranışı arasındaki ilişkide önemli bir rol oynadığını saptamıştır.

Konuya restoranlar bağlamında bakıldığında ise öncelikle tüketicilerin restoran ziyaretlerinin dışarıda yemek yeme motivasyonları ile ilgili olduğunu hatırlamakta yarar vardır. Tüketiciler için dışarıda yemek yeme motivasyonları arasında özellikle iten motivasyon faktörlerinin tüketicinin yaşam tarzı ve dolayısıyla kişisel değerlerinden kaynaklanması beklenebilir. Diğer bir ifade ile kişisel değerler dişarıda yemek yeme motivasyonlarıyla bağlantılıdır. İlgili literatürde bu bağlantıya odaklanan bir çalışma olduğunu söylemek zordur. Dolayısıyla mevcut çalışmada Schwartz'ın (1992) kişisel değer modelinden hareketle kişisel değerler dışarıda yemek yeme motivasyonlarını doğrudan etkileyen bir değişken olarak ele alınmaktadır. Bu bağlamda söz gelimi 'hazcılık' kişisel değeri (Schwartz, 1992) bir bireyin hayatında büyük yer tutuyorsa birey dışarıda yemek yediğinde eğlence, psikolojik olarak rahatlama ve hoşça vakit geçirme gibi motivasyonlarla hareket edecektir. Dolayısıyla yeni ve heyecan yaratan deneyimler, yemekle birlikte sosyalleşme ve keyifli bir atmosfer gibi daha çok hedonik bileşenlerin ağır bastığı yemek tüketimlerinin arayışı içerisinde olacaktır. Öte yandan 'güç' değerine (Schwartz, 1992) sahip olan bireyin ise sosyal statüsünü koruma veya geliştirme motivasyonuyla restoranda yiyecek tüketimine yöneleceği söylenebilir. Bir başka örnek olarak kişi geleneksel (Schwartz, 1992) değerlerle hareket ederse daha çok otantik bir yemek deneyimi arayışı içerisinde olabilir. Güvenlik veya evrenselcilik kişisel değerlerine (Schwartz, 1992) sahip tüketici ise restoranlarda sağlıklı, kaliteli, güvenli, doğaya zarar vermeyen yemekleri 
tüketme motivasyonuyla hareket edecektir. İlgili literatürün ve verilen örneklerin işaret ettiği gibi kişisel değerlerin dışarıda yemek yeme motivasyonları üzerinde bir etkisi olduğu söylenebilir ve bu görüş bir hipotez kapsamında sınanabilir. O halde çalışmanın ilk hipotezi şu şekildedir:

$\mathrm{H}_{1}$ : Tüketicilerin sahip olduğu kişisel değerler onların dışarıda yemek yeme motivasyonlarını olumlu yönde etkiler.

Tüketici bakış açısıyla restoranlar sahip oldukları nitelikler (yiyecek, konum, fiyat, servis, atmosfer vb.) üzerinden kendisi için birtakım faydalar (doyurucu, sağlıklı, lezzetli veya yeni yiyecekler; uygun bir konum veya bireysel kimliğe katkı vb.) yaratan işletmelerdir. Dolayısıyla tüketicilerin hangi restoran niteliklerine ne kadar önem verdikleri ve restoranların kendilerine hangi nitelikleri ne kadar sundukları üzerinden bir değerlendirme yaparak restoran seçimini gerçekleştirmesi beklenir. Bu süreçte restoran imajı da önemli bir rol oynar (Liu ve Tse, 2018). Çünkü restoran imajı bilişsel ve duygusal açıdan tüketicilerin bir restoranın nitelikleri ile ilgili öznel değerlendirmelerinin ve hissettiklerinin bir sonucudur (Ryu vd., 2012). Öte yandan restoran imajı belirli değerleri (hazcılık, akılcılık, güvenlik, geleneksellik, çevreye saygı, hız, güç, yenilik vb.) de yansıtır. Bu bağlamda hızlı servis sunan restoranlar akılcılık ve hız; masa servisi sunan lüks restoranlar yenilik, statü ve hedonizm ile ilişkilendirilebilmektedir. Bir tüketicinin kişisel değerleriyle uyumlu tüketimleri tercih etme eğiliminde olduğu hatırlanırsa restoran deneyimleri açısından da kendi kişisel değerleri ile örtüşen bir imaja sahip olan bir restoranı seçmesi beklenir. Diğer bir deyişle, bir tüketicinin restoran seçiminde kişisel değerlerini yansıtan restoran niteliklerini daha fazla önemseyerek bu niteliklere sahip olduğunu düşündüğü restoranları seçme olasılığı artacaktır.

Örnek vermek gerekirse tüketici yaşamında akılcılık, hız, makul fiyat gibi değerleri benimsemiş ve yaşam tarzını bunlar üzerine kurgulamışsa, alternatif restoranları servis hızı ve fiyat niteliklerini daha önemli görerek değerlendirecek ve nihayetinde söz konusu değerleri temsil eden ve muhtemelen hızlı servis sunan tarzdaki bir restoranı seçmeye yönelecektir. Diğer yandan kişi hayatında güvenliğe (Schwartz, 1992) önem verip bu değere göre davranışlarını şekillendiriyorsa sağlıklı ve kaliteli yiyecek sunmasıyla bilinen ve güvenilir bir markaya sahip olan restoranları seçme eğiliminde olacaktır. Diğer bir ifade ile restoranın markası tüketici için restoran seçiminde en çok önem verdiği niteliklerden biri olacaktır. Tüketicinin yaşamında güç değeri (Schwartz, 1992) ön plana çıkıyorsa restoranın temsil ettiği sosyal statü ve sahip olduğu ün seçimde en çok önemsenen faktörlerin başında gelecektir. İlgili literatür ve örneklerin gösterdiği üzere kişisel değerler tüketicilerin restoran seçiminde dikkate aldıkları niteliklerin bazılarının daha fazla önemsenmesine yol açabilmektedir. Bu nedenle tüketicinin kişisel 
değerleri ile restoran seçimi arasında bir bağ olduğu ve kişisel değerlerin restoran seçimini etkileyeceği düşünülmektedir. Bu bağlamda çalışmanın ikinci hipotezi şu şekildedir:

$\mathrm{H}_{2}$ : Tüketicilerin sahip olduğu kişisel değerler onların restoran seçimini olumlu yönde etkiler.

Tüketicilerin hangi restoranda nasıl bir yemek deneyimi yaşayacağında dışarıda yemek yeme motivasyonlarının belirleyici olduğu bilinmektedir (Özdemir, 2018: 54). İlgili literatür motivasyonların bireye ve zamana göre değişkenlik gösterebileceğini işaret etmektedir (Bekar ve Dönmez, 2016; Beldona vd. 2010). Şu hâlde restoran seçimi açısından tüketicinin dışarıda yemek yeme motivasyonu değiştiğinde restoran seçiminde dikkate aldığı niteliklerin önem sırası da değişecektir (Auty, 1992; Kivela 1997). Motivasyon ile restoran nitelikleri arasındaki ilişki için kuramsal açıklamayı 'hedefe dayalı yaklaşım' adıyla Ponnam ve Balaji (2014) yapmaktadır. Buna göre tüketicilerin seçimleri onların ulaşmak istedikleri hedeflere bağlıdır. $\mathrm{Bu}$ doğrultuda tüketiciler hedeflerini gerçekleştirmelerine katkı vereceğine inandıkları nitelikleri daha olumlu değerlendirirler ve seçimlerini bu nitelikler üzerinden yaparlar. Restoran seçimi açısından da tüketicilerin hedeflerini motivasyonları belirler, böylece tüketiciler motivasyonları ile uyuşan restoran niteliklerini daha çok önemli görürler ve seçimlerini yapmada bu nitelikler daha fazla etkili olur.

Örnekler vermek gerekirse, tüketici açlığını gidermek ya da kolayca yemek tüketmek motivasyonuyla hareket ettiğinde restoran seçiminde önemsediği nitelikler (komum, servis hızı, porsiyon büyüklüğü, fiyat vb.) farklı; motivasyonu kutlama ya da sosyalleşme olduğunda önemli gördüğü nitelikler (imaj, atmosfer, yiyecek çeşitliliği ve kalitesi vb.) farklı olur. Dışarıda yemek deneyimlerinde yenilik veya çeşitlilik arayışı içinde olan bir tüketici farklı mutfak kültürüyle ilgili yeni şeyler öğrenmek ve yeni yiyecekler tatmak gibi motivasyonlarla hareket ederek, bunları bulabileceğini düşündüğü bir restoranı seçmek isteyecektir. Bu restoranı seçerken de yerel yiyecek kullanımı, menü çeşitliliği, atmosfer, şefin yaratıcı ve yenilikçi tarzı gibi nitelikleri nispeten daha çok önemseyecektir. Önceki araştırmaların bulguları, kuramsal açıklamalar ve örneklerin gösterdiği gibi tüketicilerin dışarıda yemek yeme motivasyonları onların restoran seçimlerinde dikkate aldığı faktörlerin önem sıralamasını etkiler. Bu bağlamda mevcut çalışmada da motivasyonların restoran seçimi üzerindeki etkisi sınanmaktadır. $\mathrm{Bu}$ açıdan bakıldığında çalışmanın üçüncü hipotezi şu şekildedir:

$\mathrm{H}_{3}$ : Tüketicilerin dışarıda yemek yeme motivasyonları onların restoran seçimini olumlu yönde etkiler.

Mevcut çalışmanın ilk iki hipotezi çerçevesinde kişisel değerlerin tüketicilerin dışarıda yemek yeme motivasyonlarını ve restoran seçimlerini doğrudan etkileyebileceği 
öngörülmektedir. Üçüncü hipotezle birlikte motivasyonların restoran seçimini etkilemesi beklenmektedir. $\mathrm{Bu}$ durumda kişisel değerler restoran seçimini dışarıda yemek yeme motivasyonları üzerinden de etkiyebilir. Daha önce değinildiği gibi kişisel değerler sosyokültürel kaynaklıdır, tüketimden bağımsız olarak varlığını gösterir ve bireylerin kısa sürede değişime uğraması beklenmeyen yaşam tarzlarıyla ilgilidir. Bu nedenle restoran seçimleri açısından koşul bağımlılı̆ğ azaltan bir değişken olarak görülebilir. Ancak bu görüşün sınanabilmesi için kişisel değerlerin restoran seçimi üzerindeki doğrudan etkisinin sorgulanmasının yanı sıra dışarıda yemek yeme motivasyonları üzerinden de bir etkisi olup olmadığının incelenmesi gerekir. Çünkü kişisel değerler davranışları güçlü bir şekilde etkileyen ve bireyin yaşamındaki nispeten durağan olan bir faktör olarak hangi restoranda yemek yeneceği kararını doğrudan etkileyerek restoran seçiminin zamana bağlı olarak değişkenlik gösterdiği yönündeki koşul bağımlılık özelliğini azalttığı gibi hangi motivasyonlarla dışarıda yemek yendiğini de şekillendirmesi açısından dışarıda yemek yeme motivasyonlarının değişkenliğini azaltarak restoran seçimlerini nispeten daha az dinamik, yani daha az koşul bağımlı hale getirebilir. Öyleyse motivasyonların kişisel değerler ile restoran seçimi ilişkisine aracılık eden bir değişken olarak sınanması gerekir. Dolayısıyla çalışmanın son hipotezi şu şekildedir:

$\mathrm{H}_{4}$ : Tüketicilerin dışarıda yemek yeme motivasyonları, kişisel değerler ile restoran seçimi arasındaki ilişkiye aracılık eder.

Çalışmada ele alınan değişkenler arasında öngörülen ilişkiler doğrultusunda araştırmanın modeli şu şekilde gösterilebilir.

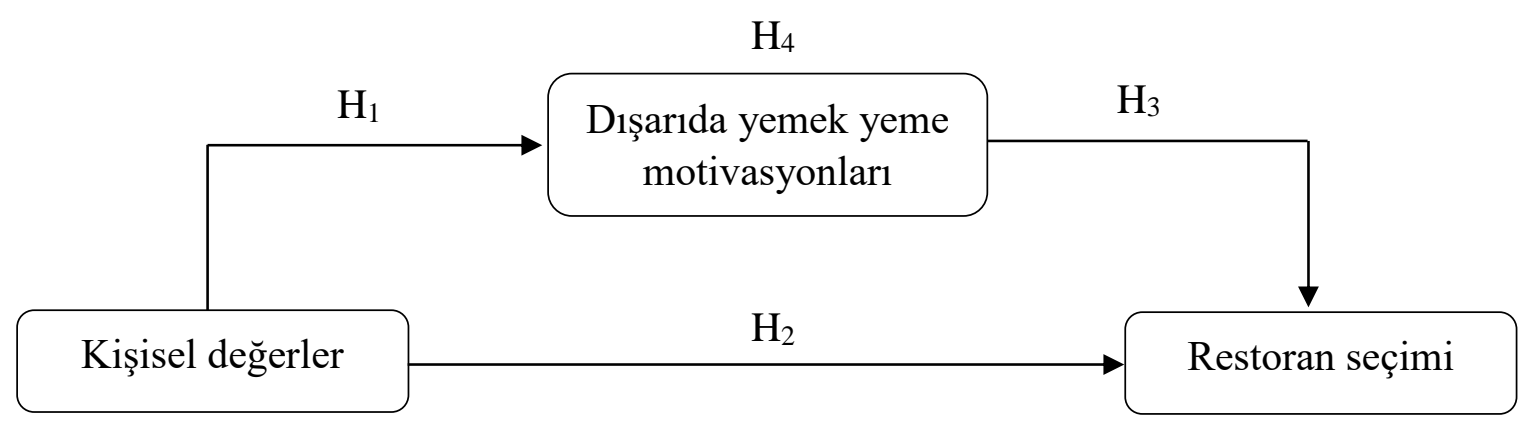

Şekil 1. Araştırma Modeli

\section{Yöntem}

$\mathrm{Bu}$ araştırma, kişisel değerlerin restoran seçimine ve dışarıda yemek yeme motivasyonlarına etkisini; motivasyonların söz konusu değişkenler arasındaki aracılık rolünü incelemeyi amaçlamaktadır. $\mathrm{Bu}$ doğrultuda araştırma kapsamında oluşturulan modelin test edilmesi amacıyla nicel araştırma yönteminden yararlanılmıştır. Çalışmada kullanılan anket üç 
bölümden oluşmaktadır. İlk bölümde araştırmanın amacı kısaca ifade edilmiş ve katılımcılara: 'Son bir yıl içerisinde herhangi bir restoranı ziyaret ettiniz mi?' şeklinde bir filtreleme sorusu yönetilmiştir. Fakat bu soruyla elenen anket formu olmamıştır. İkinci bölümde ise araştırma modelindeki bağımlı ve bağımsız değişkenlere ilişkin ölçekler yer almaktadır. Son olarak üçüncü bölümde yaş, cinsiyet, eğitim durumu gibi katılımcıların demografik özelliklerine yönelik sorular bulunmaktadır.

Araştırma kapsamında katılımcıların kişisel değerlerini ölçmek amacıyla Schwartz (2003) tarafindan oluşturulan ve Kahraman (2018) tarafından Türkçeye uyarlanan altılı likert formatındaki 21 maddelik ölçek kullanılmıştır. Ölçek kapsamında katılımcılara bazı kişileri tanımlayan ifadeler sorulmuş ve bu kişileri kendilerine ne derece benzettiklerini belirtmeleri istenmiştir (1: Bana Hiç Benzemiyor ve 6: Bana Çok Benziyor). Katılımcıların dışarıda yemek yeme motivasyonlarını ölçmek için Albayrak'ın (2014) çalışması başta olmak üzere Bekar ve Dönmez (2016); Nişancı vd. (2018) ve Ertürk'ün (2018) çalışmalarında yer verilen dışarıda yemek yeme nedenlerinden yararlanılmıştır. Buna göre katılımcılara dışarıda yemek yeme amaçlarına ilişkin dokuz ifade (kolaylık, sosyalleşme, arkadaşlarla birlikte vakit geçirme, eğlence, zaman tasarrufu, ekonomik olma, statü/prestij sağlama, farklılık ve özel nedenler) sunulmuş ve katılım düzeylerine göre cevap vermeleri istenmiştir (1: Kesinlikle Katılmıyorum ve 5: Kesinlikle Katılıyorum). Benzer şekilde beşli likert formatında olan restoran seçimi ölçeği için Albayrak’ın (2014) çalışmasından yararlanılmıştır. Bahsi geçen ölçekte katılımcıların restoran seçimine yönelik ifadeler yer almaktadır. Katılımcılardan bu ifadeleri restoran seçimlerinde ne derece önem arz ettiğine dair yanıtlamaları istenmiştir (1: Hiç Önemli Değil ve 5: Son Derece Önemli).

Anket formunda yer alan soruların anlaşılırlığını belirlemek amacıyla 129 kişinin katılımı ile pilot çalışma gerçekleştirilmiştir. İlgili çalışma sonucunda tüm soruların kolaylıkla anlaşıldığı görülmüştür. Verilerin normal dağılım gösterip göstermediği çarpıklık ve basıklık değerleri ile incelenmiştir. Değişkenlerin çarpıklık değerlerinin -1.400 ile -0.441 ve basıklık değerlerinin +1.365 ile +0.432 arasında olduğu tespit edilmiştir. Böylece ilgili değerler \pm 2 değerini aşmadığından verilerin normal dağılım gösterdiği ortaya çıkmıştır (Kline, 2011). Aynı zamanda söz konusu ölçeklerin güvenirlik katsayıları kişisel değerler ölçeği için 0,78; dışarıda yemek yeme motivasyonları ölçeği için 0,71 ve restoran seçimi ölçeği için 0,79 olarak bulunmuştur. Bu bağlamda yapılan açıklayıcı faktör analizi sonuçlarına göre kişisel değerler ölçeğinin toplam açıklanan varyans oranının \% 59,237; restoran seçimi ölçeğinin \% 58,998 ve motivasyon ölçeğinin \% 62,925 olduğu tespit edilmiştir. Aynı zamanda kişisel değerler ölçeği dört faktör; motivasyon ölçeği tek faktör ve restoran seçimi ölçeği dört faktörlü yapıdan 
oluşmuştur. Bu durumda ölçeklerin orijinal halinde olduğu gibi faktörlere (kişisel değerler dört faktör; dışarıda yemek yeme motivasyonları tek faktör; restoran seçimi dört faktör) ayrıldığı görülmüştür. Dolayısıyla mevcut anket formunun ana çalışma için aynı şekilde uygulanmasına karar verilmiştir.

Çalışma kapsamında örneklem belirlenirken amaçlı ve kartopu örnekleme yöntemleri bir arada kullanılmıştır. Amaçlı örnekleme yöntemi kapsamında çalışmada örneklem çerçevesi oluşturulurken katılımcıların 18 yaşından büyük olmasına ve son bir yıl içinde herhangi bir restoranı ziyaret etmesine dikkat edilmiştir. Aynı zamanda, çevrimiçi uygulama yapıldığından dolayı, belirlenen örneklem sayısına ulaşabilmek adına kartopu örnekleme yöntemi kullanılmıştır. Kartopu örnekleme yöntemi kapsamında araştırmacıların ulaşabileceği ilk örneklem birimi belirlenmiş ve bu birim üzerinden elde edilen veriler bazında bir sonraki birime geçilmiştir. Bu işlem belirlenen örneklem sayısına ulaşana kadar tekrar edilmiştir. Diğer yandan örneklem büyüklüğü için Krejcie ve Morgan (1970) tarafindan 10.000'den fazla birey içiren evrenler için önerilen ve 0,05 anlamlılık ve hata düzeyinde belirlenen 384 sayısı bu çalışma kapsamında örneklem için yeterli bulunmuştur. Kartopu örneklemi kapsamında sosyal medya aracılığıyla uygulanan çevrimiçi anket ile önce yakın çevreye ulaşılmış ardından ulaşılan kişilerin önerisi doğrultusunda onların yakın çevresi ile iletişime geçilmiştir. Böylece 2020 yılının Ekim-Aralık ayları içerisinde gerçekleşen çevrimiçi anket uygulaması kapsamında soru formları 1200 kişiye yollanmış 398 kişiden dönüş alınmıştır. Yapılan inceleme sonrasında yedi anket formu elenerek 391 adet anket formu geçerli olarak kabul edilmiştir.

Araştırma kapsamında sunulan model doğrultusunda analizler iki aşamada yapılmıştır. İlk aşamada doğrulayıcı faktör analizi (DFA) ile ölçüm modeli test edilerek ölçeklere ilişkin geçerliğe ve güvenirliğe dair bulgular elde edilmiştir. İkinci aşamada ise Yapısal Eşitlik Modeli (YEM) ile araştırmanın hipotezleri test edilmiştir. Uyum iyiliği değerleri incelenerek modelin uyumu değerlendirilmiş ve standartlaştırılmış yol katsayıları ile hipotezlerin öngördüğü ilişkiler istatistiki açıdan incelenmiştir.

\section{Bulgular}

\subsection{Demografik Bulgular}

Katılımcıların demografik bilgileri incelendiğinde \%65'inin kadın ve \%63'ünün 25-34 yaşları arasında olduğu ortaya çıkmıştır. Aynı zamanda katılımcıların büyük bir kısmının (\%72) 5500 TL ve üzeri gelir elde ettikleri görülmektedir. Medeni durum ve eğitim düzeyi açısından ise katılımcıların \%52'sinin bekâr; \%74'ünün lisansüstü eğitime sahip olduğu bulunmuştur (Tablo $1)$. 
Tablo 1. Katılımcıların Demografik Özelliklerine İlişkin Bulgular

\begin{tabular}{lcc}
\hline \multicolumn{1}{c}{ Demografik Özellik } & $\mathrm{f}$ & $(\%)$ \\
\hline Cinsiyet $(n=391)$ & & \\
Erkek & 136 & 34.8 \\
Kadın & 255 & 65.2 \\
Yaş $(n=391)$ & & \\
$18-24$ & 43 & 11.0 \\
$25-34$ & 250 & 63.9 \\
$35-44$ & 87 & 22.3 \\
$45-54$ & 7 & 1.8 \\
$55-64$ & 2 & 0.5 \\
65 ve üzeri & 2 & 0.5 \\
Eğitim durumu $(n=391)$ & & \\
Lise & 3 & 0.8 \\
Üniversite & 97 & 24.8 \\
Lisansüstü & 291 & 74.4 \\
Gelir $(n=391)$ & & \\
1000 TL ve aşağıS1 & 21 & 5.4 \\
1001-2500 TL & 10 & 2.6 \\
2501-4000 TL & 8 & 2.0 \\
4001-5500 TL & 19 & 4.9 \\
5501-7000 TL & 283 & 72.4 \\
7001 TL ve üzeri & 50 & 12.8 \\
Medeni durum $(n=391)$ & & 52.4 \\
Bekar & 205 & 47.6 \\
Evli & 186 & \\
\hline
\end{tabular}

\subsection{Güvenirlik ve Geçerliğe İlişkin Bulgular}

Ölçeklerin güvenirliliğine ilişkin Cronbach's Alpha değerleri kişisel değerler için 0,892; restoran seçimi için 0,846 ve dışarıda yemek yeme motivasyonları için 0,714 olarak tespit edilmiştir. Bu değerlerin ölçeklerin kabul edilebilir seviyede güvenilir olduklarına işaret ettiği görülmektedir (Murphy ve Davidshofer, 1988). Kullanılan ölçeklerin geçerliliğini test etmek amacıyla ise doğrulayıcı faktör analizi (DFA) yapılmıştır. Bu kapsamda kişisel değerler ve restoran seçimi ölçeğinin dört faktörlü; dışarıda yemek yeme motivasyonları ölçeğinin ise tek faktörlü yapısı test edilmiştir. Kişisel değerler ve restoran seçimi için birinci düzey; dışarıda yemek yeme motivasyonları için ise tek faktörlü DFA yapılmıştır (Tablo 2). 
Tablo 2. Ölçüm Modeline İlişkin DFA Sonuçları

Yapılar
Kişisel Değerler
Faktör 1: Yeniliğe Açıklık
Yeni fikirler bulmak ve yaratıcı olmak onun
için önemlidir. İşleri kendine özgü yollarla
yapmaktan hoşlanır.
Sürprizleri sever ve her zaman yeni şeyler
denemek için can atar. Hayatta pek çok farklı
şeyler denemenin önemli olduğunu düşünür.
Hayattan zevk almak onun için önemlidir.
Kendisini şımartmaktan hoşlanır.
Yaptığı işler hakkında kendi başına karar
vermek onun için önemlidir. Özgür olmak
ister, başkalarına bağımlı olmak istemez.
Eğlenmek için her firsatı kollar. Zevk veren
şeyleri yapmak onun için önemlidir.
Faktör 2: Tutuculuk
Onun için güvenli bir çevrede yasamak
önemlidir. Güvenliğini tehlikeye sokabilecek
her şeyden kaçınır.
İnsanların kendilerine
yapmaları gerektiğine inanır. İnsanlarınenleri her
zaman, hatta başkaları izlemiyorken bile,
kurallara uymaları gerektiğini düşünür.
Devletin her türlü tehdide karşı güvenliğini
sağlaması onun için önemlidir. Devletin,
vatandaşlarını savunabilecek güçte olmasını
bekler.
Faktor 3: Öz-aşkıı

\section{Faktör 3: Öz-aşkınlık}

Dünyada herkesin eşit muamele görmesinin önemli olduğunu düşünür. Hayatta herkesin eşit firsatlara sahip olması gerektiğine inanır. Kendisinden farklı olan insanları dinlemek onun için önemlidir. Onlarla aynı fikirde olmadığında bile onları anlamak ister.

Çevresindeki insanlara yardım etmek onun için çok önemlidir. Onların iyi olmalarını önemser.

Arkadaşlarına sadık olmak onun için önemlidir. Kendisini ona yakın olan insanlara adamak ister.

İnsanların doğayı korumaları gerektiğine gönülden inanır. Çevreyi korumak onun için önemlidir.

\section{Faktör 4: Özgenişletim}

0.793

Onun için yeteneklerini göstermek çok önemlidir. İnsanların onun yaptıklarına hayran olmasını ister.

Çok başarılı olmak onun için önemlidir. Elde ettiği başarıların diğerleri tarafından onaylanmasını bekler.

Başkalarından sayg1 görmek onun için önemlidir. İnsanların onun söylediklerini yapmalarını ister. 
Restoran Seçimi

Faktör 1: Restoran Özellikleri

Restoranın atmosferi

Restoranın güven vermesi

Restoranın temizliği

Faktör 2: Yiyecek-İçecek Özellikleri

Yemeklerin çeşitliliği

Farklı mutfakların varlığı

Yemeklerin besin değeri

Faktör 3: Hizmet

Çalışanların davranışları

Servis hizı

Çalışanların yetkinliği

Faktör 4: Parasal Değer

Yemeklerin fiyatı

Ödediğim paranın karşılığını almak

Ödeme kolaylığının bulunması

Dişarıda Yemek Yeme Motivasyonları

Dışarıda yemek yemek bana kolaylık sağlar.

Dışarıda yemek yeme amacım aile,

arkadaşlarla birlikte olmaktır.

Dışarıda yemek yeme amacım 0.866

sosyalleşmektir.

Eğlenceli olduğu için dışarıda yemek yerim.

Farklılık yarattığı için dişarıda yemek yerim.

Özel nedenlerden dolayı (iş, kutlama gibi)

dişarıda yemek yerim.
0.846

0.913

0.855

0.784

0.807

0.809

0.547

0.816

0.815

0.854

0.662

0.728

0.729

0.480

0.874

0.783

0.698

0.482

0.714
0.88

0.72

0.77

0.53

0.86

0.68

0.75

0.50

0.85

Ölçüm modeline yönelik yapılan doğrulayıcı faktör analizi sonucu dört faktör ve 21 maddeden oluşan kişisel değerler ölçeğinden beş; dört faktör ve 19 maddeden oluşan restoran seçimi ölçeğinden yedi; tek faktör ve dokuz maddeden oluşan motivasyon ölçeğinden ise dört maddenin faktör yüklerinin 0.40 değerinden düşük olduğu (Gürbüz ve Şahin, 2018) tespit edilmiş ve ilgili maddeler ölçüm modelinden çıkarılarak analiz tekrar edilmiştir. Bu analiz sonucunda tüm ölçüm modeline yönelik uyum iyiliği değerlerinin kabul edilebilir olduğu kanısına varılmıştır (CMIN/DF=2,844; GFI=,831; CFI=,811; RMSEA=,069).

Ölçeklere ilişkin güvenilirlik için yapı güvenirliğ $i$; yakınsama geçerliliği için ise açıklanan ortalama varyans değerleri hesaplanmıştır. Ölçüm modellerine ilişkin değerlerin $A O V>.5$; $Y G>.7 ; \quad Y G>A O V$ şeklinde olması önerilmektedir (Gürbüz, 2019). Bu bağlamda ilgili ölçeklerin her birinin AOV ve YG değerleri önerilen eşik değerlerini aşmaktadır (Tüm $Y G$ değerleri .70'in üzerindedir; tüm $A O V$ değerleri .50'nin üzerindedir). Dolayısıyla söz konusu ölçeklerin AOV ve YG değerleri açısından yüksek güvenilirliğe ve yakınsama geçerliliğine sahip olduğu tespit edilmiştir. Ayrışma geçerliliği için ise AOV ve MPVK (maksimum paylaşılan varyansın karesi) değerleri ile değişkenler arası korelasyon katsayıları karşılaştırılmıştır. Faktörlere ait AOV (AVE) değerlerinin MPVK (MSV) değerlerinden yüksek 
olması ve $\sqrt{ }$ AOV ( $\mathrm{AVE}$ ) değerlerinin de faktörler arası korelasyonlardan yüksek olması dolayısıyla ölçüm modelinin ayrışma geçerliliğine sahip olduğu tespit edilmiştir (Tablo 3).

Tablo 3. Faktörlere Ait Korelasyon Katsayıları

\begin{tabular}{lccccc}
\hline \multicolumn{1}{c}{ Faktörler } & AOV (AVE) & $\begin{array}{c}\text { MPVK } \\
\text { (ASV) }\end{array}$ & 1 & 2 & 3 \\
\hline 1. Restoran Seçimi & 0,700 & 0,452 & 0,837 & & \\
2. Motivasyonlar & 0,514 & 0,365 & 0,604 & 0,654 & 0,878 \\
3. Kişisel Değerler & 0,771 & 0,452 & 0,672 & 0,552 &
\end{tabular}

Not: İtalik şekilde belirtilen değerler $(\sqrt{ } \mathrm{AOV})$ değerlerini göstermektedir.

\subsection{Yapısal Eşitlik Modeline İlişkin Bulgular}

Ölçme modelinin doğrulanmasından sonra örtük değişkenli yapısal model üzerinden araştırma hipotezleri test edilmiştir (Tablo 4). Öncelikle yol analizi neticesinde elde edilen uyum iyiliği değerlerinin $(\mathrm{CMIN} / \mathrm{DF}=2,401 ; \mathrm{GFI}=, 845 ; \mathrm{CFI}=, 863$; $\mathrm{RMSEA}=, 060)$ kabul edilebilir düzeyde olduğu görülmüştür. Ardından standart yol katsayıları ve anlamlılık düzeylerine bakılarak hipotezler sırası ile test edilmiştir. $\mathrm{H}_{1}$ hipotezi doğrultusunda kişisel değerlerin motivasyonları anlamlı şekilde etkilediği $(\beta=0.44 ; \mathrm{p}<0.01)$ tespit edilmiştir. $\mathrm{Bu}$ durumda $\mathrm{H}_{1}$ hipotezi araştırma bulguları ile desteklenmiştir. Daha sonra $\mathrm{H}_{2}$ hipotezi kapsamında kişisel değerlerin restoran seçimini istatistiki olarak anlamlı şekilde etkilediği $(\beta=0.47$; $\mathrm{p}<0.01)$ görülmüştür. Böylece $\mathrm{H}_{2}$ desteklenmiştir. Araştırmanın üçüncü hipotezi çerçevesinde dışarıda yemek yeme motivasyonlarının restoran seçimini anlamlı şekilde etkilediği $(\beta=0.28 ; \mathrm{p}<0.01)$ bulgusuna ulaşılmış ve $\mathrm{H}_{3}$ hipotezinin de desteklendiği görülmüştür.

Tablo 4. Yapısal Eşitlik Modeline İlişkin Sonuçlar

\begin{tabular}{ccccc}
\hline Hipotezler & S. Y. K. & $\mathrm{R}^{2}$ & p değeri & Sonuç \\
\hline $\mathrm{H}_{1}$ (Kişisel değerler $\longrightarrow$ Motivasyonlar) & 0.44 &, 18 & 0.01 & Desteklendi \\
$\mathrm{H}_{2}$ (Kişisel değerler $\longrightarrow$ Restoran seçimi) & 0.47 &, 23 & 0.01 & Desteklendi \\
$\mathrm{H}_{3}$ (Motivasyonlar $\longrightarrow$ Restoran seçimi) & 0.28 &, 27 & 0.01 & Desteklendi
\end{tabular}

(S.Y.K.=Standartlaştırılmış Yol Katsayıları; Uyum İstatistikleri: CMIN/DF=2,440; GFI=,845; CFI=,853; RMSEA=,061)

Araştırmanın son hipotezi $\left(\mathrm{H}_{4}\right)$ kişisel değerler ile restoran seçimi ilişkisinde dışarıda yemek yeme motivasyonlarının aracılık rolünün test edilmesini gerektirmektedir. Elde edilen sonuçlara göre dışarıda yemek yeme motivasyonları analize dahil edildikten sonra kişisel değerlerden restoran seçimine giden yol katsayısında düşüş yaşandığ $1(\beta=0.34 ; p<0.01)$, ancak etkinin hala anlamlı olduğu gözlemlenmiştir. $\mathrm{Bu}$ bağlamda dışarıda yemek yeme 
motivasyonları, kişisel değerlerin restoran seçimi üzerindeki etkisini azalttığı için kısmi aracılık meydana gelmiştir. İlgili değişkenin aracılık rolünün anlamlı olup olmadığı ise 'bootstrap' yöntemi ile \% 95 güven aralığında test edilmiştir (MacKinnon vd. 2002). Söz konusu yöntemin sonuçlarına göre kişisel değerlerin restoran seçimine dolaylı etkisinin alt güven sınırı ,057; üst güven sınırı ise ,208 olarak bulunmuştur. Bu doğrultuda kişisel değerlerin motivasyonlar aracılığıyla restoran seçimi üzerindeki dolaylı etkisinin anlamlı olduğu tespit edilmiştir $(\beta=.119, \% 95)$. Bu sonuçlar, kişisel değerler ve restoran seçimi arasındaki ilişkide dışarıda yemek yeme motivasyonlarının kısmi de olsa bir aracılık etkisinin olduğunu göstermektedir. $\mathrm{Bu}$ durumda $\mathrm{H}_{4}$ hipotezi araştırma bulguları ile desteklenmiştir.

Dolayll etki: $\beta=0.119, \% 95$ CI $(0.057,0.208)$

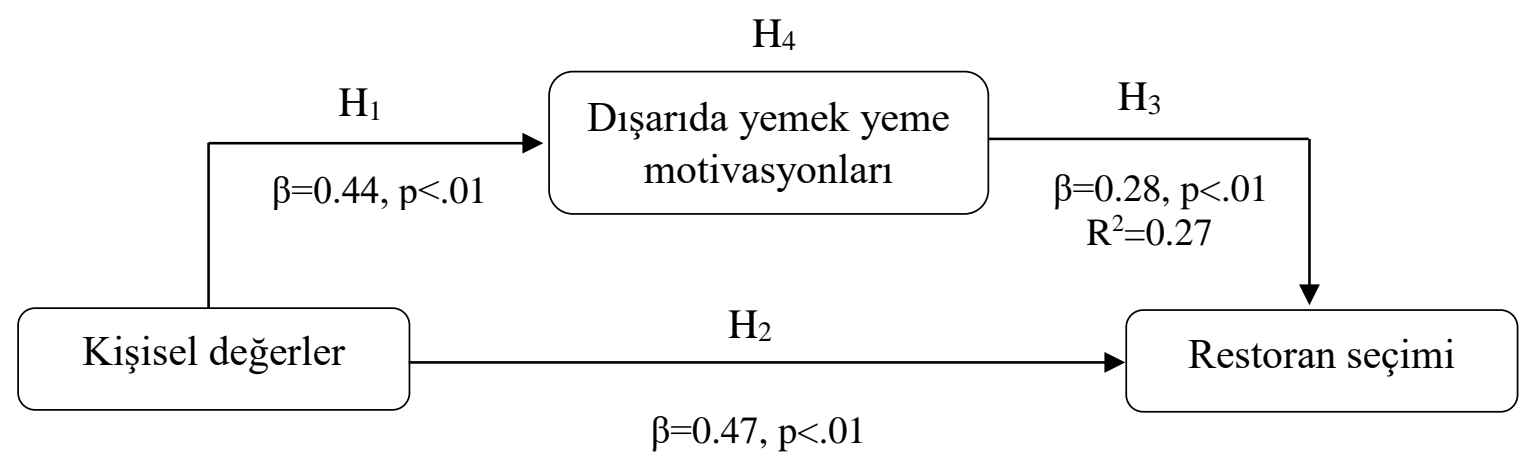

Not: Parantez içindeki değerler alt ve üst güven aralığı (CI) değerleridir. Bootstrap yeniden örnekleme=2000. $(\mathrm{n}=391)$

Şekil 2. Kişisel Değerler ve Restoran Seçimi İlişkisinde Dışarıda Yemek Yeme Motivasyonlarının Aracılık Rolü

\section{Tartışma}

Kişisel değerler doğası gereği bireyden bireye değişkenlik gösterebilir. Dolayısıyla kişisel değerlerdeki bireysel farklılıklar dışarıda yemek yeme motivasyonlarının ve restoran seçiminin bireye göre değişmesine neden olabilir. Mevcut çalışmanın bulguları da bunu göstermektedir. $\mathrm{Bu}$ hali ile restoran seçimi bir dereceye kadar değişken ve koşul bağımlıdır. Aslında mevcut çalışmanın ortaya koyduğu görüşe göre tüketicilerin restoran seçimleri açısından asıl soru koşul bağımlılığın var olup olmadığı değil ne kadar düşük veya yüksek olduğudur. Oysa ilgili literatürdeki çalışmalar restoran seçimini motivasyonlar başta olmak üzere çok sayıda faktörün etkisiyle bireye, zamana ve mekâna göre değişkenlik göstermesi nedeniyle neredeyse tamamıyla koşul bağımlı görmektedir. Ancak bu çalışmaların kişisel değerlerin etkisini dikkate almadığı da bilinmektedir. En azından zaman boyutuyla kişisel değerlerin etkisi ile hem motivasyonlardaki hem restoran seçimindeki değişkenliğin azalması olanaklı olabilir. Çünkü 
bir bireyin kişisel değerlerinin zaman içinde değişimden çok tutarlılık gösterdiği düşünüldüğünde kişisel değerlerin etkisi altında olan dişarıda yemek yeme motivasyonları ve restoran seçiminin de bir birey için zamanla tutarlılık sergilemesi olanaklıdır.

Kişisel değerler dışarıda yemek yeme motivasyonları açısından özellikle iten faktörleri belirleyebilir. Bilindiği üzere iten faktörler bireyin kendisi veya içindeki çevreden kaynaklanan ve onu belirli bir tüketim biçimine yönlendiren yenilik arayışı, rutinden uzaklaşma vb. motivasyon faktörleridir (Kim vd. 2003). Bu faktörlerin oluşmasında bireyin kişisel değerleriyle doğrudan bağlantılı olan yaşam tarzı çok belirleyicidir. Kişisel değerler de bireyi sahip olduğu değerlerle uyumlu tüketim davranışlarına yöneltmesi nedeniyle iten motivasyon faktörleri için önemli bir kaynak olabilmektedir. Sözgelimi restoranlar bağlamındaki tüketimlerde son yıllarda yaygınlaştı̆̆ kabul edilen çevreye duyarlılık, yiyeceğin kökenini bilme, kültüre saygı ve sağlıklı beslenme gibi davranışlar ile tüketiciler satın alma kararlarının ve tüketim eylemelerinin hem kendileri hem toplum hem de çevre üzerindeki etkilerini dikkate almakta ve bu yönde daha bilinçli kararlar vermek istemektedir. Doğal olarak bu davranışlar tüketicilerin dışarıda yemek yeme motivasyonlarını ve restoran seçimlerini de etkilemektedir. Bu tarz kararların arkasında tüketicilerin Schwartz'ın (1992) sıraladığı güvenlik (ulusal güvenlik, toplumsal düzen, temiz olma), iyilikseverlik (yardımseverlik, dürüstlük, bağışlayıcı olma), öz yönelim (yaratıcılık, merak, özgünlük) ve evrenselcilik (geniş fikirlilik, sosyal adalet, eşitlik, çevreyi koruma) değerlerinin olması beklenir. Çünkü tüketiciler restoran seçimlerinde kişisel değerlerini yansıtan restoran niteliklerini daha çok önemseme eğiliminde olurlar. $\mathrm{Bu}$ faktörlere göre yapılan seçimler de çevreye duyarlılık, kültüre saygı ve sağlıklı beslenmeye uygun olan ve zaman içinde tutarlılık sergileyen davranışlar olarak görülebilir. Üstelik bu davranışların bireyin yaşam tarzını ve kimliğini bulmak, bunu göstermek veya geliştirmek istemesi açısından da kişisel değerlerle ilişkisi olduğu söylenebilir.

Öte yandan kişisel değerlerin koşul bağımlılığı azaltıcı etkisi sürekli olarak aynı restoranın seçilmesi anlamında bir tutarlı davranışı zorunlu kılmaz. Daha çok tüketicilerin restoran seçiminde önemsedikleri faktörlerin sıralamasında bir tutarlılığı beraberinde getirir. $\mathrm{Bu}$ da restoran seçimleri için tüketicilerin oluşturduğu uyarılmış setin (Auty, 1992; Kivela 1997; Cullen, 2004) içeriğini şekillendirmede belirleyici olur. Çünkü tüketiciler kişisel değerleri ile uyuşan restoran niteliklerini daha çok önemseyerek ilk sıralamayı ve bunu sonucu olarak da uyarılmış seti oluşturabilirler. Söz gelimi evrenselcilik değerlerine sahip bir tüketicinin restoranların çevreye duyarlılığını önemsemesi nedeniyle içerisinden nihai seçimi yapacağı uyarılmış restoran seti de büyük olasılıkla çevreye duyarlı uygulamaları olan restoran seçeneklerinden oluşur. Öte yandan kişisel değerler ödünleşim (Koo vd. 1999; Jung vd. 2015) 
açısından da koşul bağımlılığı azaltıcı bir etki gösterebilir. Tüketiciler kişisel değerlerine göre ödün vermeyecekleri restoran niteliklerini belirleyebilirler. Söz gelimi iyilikseverlik değerine sahip bir tüketici yerel kültürlerin korunması ve yerel ekonominin desteklenmesi için bir restoranın sunduğu yiyeceğin kökenini restoran seçiminde asla vazgeçmeyeceği bir nitelik olarak görebilir. Böylece yiyeceğin kökeninden ödün vermeden yeri geldiğinde servis kalitesi, konum, fiyat vb. niteliklerden vazgeçerek restoran seçimleri yaptığında davranışında zaman içinde bir değişkenlikten çok bir tutarlılık gözlemlemek olanaklı olabilir.

\section{Sonuç}

$\mathrm{Bu}$ araştırma bireylerin kişisel değerleri, dışarıda yemek yeme motivasyonları ve restoran seçimleri arasındaki ilişkileri incelemiştir. Kişisel değerler Schwartz'ın (1992) değer teorisinin sunduğu kavramsal çerçeve içinde ele alınmıştır. Bu bağlamda çalışmanın 'kişisel değerlerin dışarıda yemek yeme motivasyonlarını $\left(\mathrm{H}_{1}\right)^{\prime}$ ve 'restoran seçimini etkilediği $\left(\mathrm{H}_{2}\right)^{\prime}$, 'motivasyonların restoran seçimini etkilediği $\left(\mathrm{H}_{3}\right)$ ve dahas1 'kişisel değerler ile restoran seçimi ilişkisinde aracılık rolü oynadığı $\left(\mathrm{H}_{4}\right)$ ' şeklindeki dört hipotezin tamamı araştırma bulguları ile desteklenmiştir.

Kuramsal açından bakılınca mevcut çalışmada kişisel değerlerin etkisi ile restoran seçiminin tamamıyla koşul bağımlı olup olmadığının tartışılabileceği ileri sürülmektedir. Buna göre kişisel değerlerinin etkisini güçlü şekilde hisseden tüketiciler sahip oldukları değerlerle uyuşan tüketim davranışları sergiler ve bu da bireysel düzeyde tüketicilerin restoran seçiminde önemsedikleri faktörlerin sıralamasında bir tutarlılı̆̆ beraberinde getirir. Öte yandan kişisel değerlerin etkisi ile motivasyonlardaki değişkenliğin azalması da söz konusudur, çünkü kişisel değerler bir birey için dişarıda yemek yeme motivasyonlarının zaman içinde tutarlık sergilemesini sağlayabilir. Nihayetinde motivasyonların oluşmasında, restoran seçimleri için tüketicilerin oluşturduğu uyarılmış setin içeriğinin şekillenmesinde ve ödün verilmeyen niteliklerin belirlenmesinde kişisel değerler etkili olmaktadır. Böylece bir birey kişisel değerleri ile uyumlu dört ve beş restoran seçeneğinden oluşan bir uyarılmış set içinden belli niteliklerden ödün vermeden seçim yaptığı ölçüde restoran seçimlerinde koşul bağımlılığın düzeyi düşük olabilmektedir. Ancak koşul bağımlılık tamamen ortadan kalkmamaktadır, çünkü kişisel değerler bireyden bireye değişebilir ve böylece restoran seçiminin de bireye göre değişkenlik göstermesi kaçınılmazdır.

Pratik açıdan mevcut çalışmanın bulguları kuşkusuz restoranların hizmet sunmak istedikleri tüketicilerin hangi kişisel değerlere sahip olduğunu anlamalarının ne kadar önemli olduğunu göstermiştir. Ancak bunun kadar restoranların mevcut durumlarına ilişskin nesnel bir 
değerlendirme (SWOT veya Değer Zinciri Analizi gibi yöntemler kullanılabilir) yaparak hangi kişisel değerlerle uyuşan nitelikleri sunduklarını da gözden geçirmeleri gerekir. Bu bağlamda sadece hedef pazarlardaki tüketicilerin kişisel değerleri ile restoranın sunduğu nitelikler arasında bir uyuşmanın olup olmadığı değil niteliklerin sunumunda ne kadar iyi bir performans gösterildiğinin de değerlendirilmesi şarttır. Bu değerlendirmede hem müşteri beklentilerinin karşılanması hem de rakiplere göre sergilenen performans açsısından özenli bir analiz yapılması gerekir. Bu sayede restoranlar hedefledikleri tüketici grubunun restoran seçiminde kullandığ1 uyarılmış set içinde yer alıp almadığını, eğer içindeyse bu sete göre hangi nitelikler üzerinden hangi restoranlarla rekabet içinde olduğunu kestirebilir.

Restoranların nasıl bir imaj yansıttıkları da hedef pazarlarındaki tüketicilerin kişisel değerleriyle örtüşen niteliklerini göstermeleri açısından çok önemlidir. Örneğin yeniliğe açık kişilerin restoran seçiminde en fazla önem verdiği nitelik yiyecek çeşitliliği ve atmosfer; en az önem verdiği nitelik ise yiyeceklerin fiyatı olabilir. Öte yandan tutuculuk kişisel değeri geleneksel, alışageldiği tutumları devam ettiren, konfor alanından çıkmayan bireyleri tanımlamaktadır. Bu kişisel değere sahip bireylerin restoran seçiminde en çok önem verdikleri nitelikler restoranların kişiye güven vermesi, rahat bir ortam sunması, bilinir ve temiz olması vb. olabilir. Örneklerin de gösterdiği gibi restoranların hangi kişisel değerlere sahip olan tüketicilere hangi niteliklerle ulaşacaklarını belirlemeleri ve buna göre bir imaj inşa etmeleri gerekir. Kişisel değerleri ve yaşam tarzını esas alarak pazar bölümlendirmesi yapmayı ve hedef pazarını seçmeyi tercih eden bir restoran işletmesi için sosyal medya başta olmak üzere farklı pazarlama kanalları ile yapılacak tanıtımların yanı sıra restoranın konumu, fiyatları, atmosferi, menü tasarımı ve hatta tabak tasarımı imajla yansıtılmak istenen kişisel değerlere vurgu yapacak şekilde düzenlenebilir. Böylece hedef pazarındaki tüketicilerin kişisel değerleri ile uyumlu nitelikleri başarılı bir şekilde sunmayı başaran restoranlar kişisel değerlerin restoran seçimlerinde önemsenen nitelikleri zaman içinde tutarlı hale getirmesi nedeni ile sadık bir müşteri kitlesini korumayı başarabilir.

Her akademik çalışmada kaçınılmaz olarak görüldüğü üzere bu araştırmada da bazı sınırlılıklar mevcuttur. Çalışma kapsamında kolayda örnekleme yöntemi kullanılmış, örneklemde yer alan bireylere çevrim içi olarak ulaşılmıştır. Bunun da muhtemel bir sonucu olarak örneklemde lisansüstü eğitime sahip kişilerin ağırlıkta olduğu gözlemlenmiştir. Dolayısıyla bu araştırma kapsamında bulguların restoran deneyimi yaşayan tüm tüketicilerin davranışlarını tanımlaması söz konusu değildir. Öte yandan ölçeklerin geçerliği için her birinden madde çıkarılması gerekmiştir. Bu da anket formalarının pandemi koşulları nedeniyle çevrim içi olarak yapılmasına bağlanabilir. İleriki araştırmalarda benzer bir araştırma modelinin 
yüz yüze toplanan veriler üzerinden test edilmesi önerilir. Mevcut araştırmada hipotezleri test etmeye uygun olduğu düşünüldüğünden nicel araştırma yaklaşımından yararlanılmıştır. Dolayısıyla araştırma modelindeki değişkenler arasındaki ilişkiler istatistiki olarak sınanabilmiş, ancak her bir değişken için örneklemdeki bireylerin düşünce, deneyim ve yorumlarını esas alan derinlemesine bir inceleme yapılamamıştır. Restoran seçimi ve dışarıda yemek yeme motivasyonları ilgili literatürde nispeten daha çok incelenmiş olgular olmakla birlikte kişisel değerler restoranlar bağlamında pek ele alınmamıştır. Bu nedenle en azından kişisel değerlerin restoranlar bağlamındaki tüketici deneyimlerinde oynadığı role ilişkin derinlemesine bir kavramsallaştırma yapabilmek için gelecekteki araştırmalarda nitel araştırma yaklaşımından yararlanılabilir. Böylece mevcut çalışmada elde edilen bulgulara ve restoran seçimlerinin koşul bağımlığı açısından gerçekleştirilen tartışmaya ilişkin yeni yorumlar yapmaya olanak verebilecek yeni bulgular elde edilebilir.

Mevcut çalışma kavramsal açıdan kişisel değerleri kültür ve yaşam tarzı ile ilişkili görmektedir. Ancak araştırma modelinde bu iki değişkene yer verilmemiştir. Bu bağlamda gelecekte restoranlar bağlamında yapılacak araştırmalarda kişisel değerler kültürel farklılıkları da gözetecek şekilde incelenebilir. Böylece restoran seçiminde kültürler arası farklılıkların saptanması ve kişisel değerler üzerinden tartışılması da olanaklı olacaktır. Dahası kişisel değerler ve restoran seçimi ilişkisi gastronominin turizmdeki artan rolü de dikkate alınarak turizm bağlamında da incelenebilir. Söz gelimi turistlerin yerel yiyecek tüketme niyetleri ve yerel restoranlara ilişkin seçimlerinde kişisel değerlerin rolü araştırılabilir. Mevcut çalışmada restoran türleri (masa servisi sunan veya hızlı servis sunan gibi) açısından bir ayrım yapılmamıştır. İleriki araştırmalarda kişisel değerlerin hem motivasyonlar hem seçim üzerindeki etkisi farklı restoran türleri açısından da incelemeye alınabilir. 


\section{KAYNAKÇA}

Akova, O., Çifçi, İ., Atsız, O. \& Gezeroğlu, B. 2017. Understanding the Motivational Factors of Dining Out: A Study at Fatih Kadınlar Bazaar in Istanbul. Tourismos: An International Multidisciplinary Journal of Tourism, 11(1), 19-38.

Albayrak, A. 2014. Müşterilerin Restoran Seçimlerini Etkileyen Faktörler: İstanbul Örneği. Anatolia: Turizm Araştırmaları Dergisi, 25(2), 190-201.

Ali, J. \& Nath, T. 2013. Factors Affecting Consumers' Eating-Out Choices in India: Implications for the Restaurant Industry. Journal of Foodservice Business Research, 16(2), 197-209.

Alonso, A. D., O’Neill, M., Liu, Y. \& O’Shea, M. 2013. Factors Driving Consumer Restaurant Choice: An Exploratory Study From the Southeastern United States. Journal of Hospitality Marketing \& Management, 22, 547-567.

Arıker, Ç. 2012. Tüketicilerin Restoran Seçiminde Kullandıkları Seçim Kriterleri İle Demografik Özellikleri Arasındaki İlişki. Öneri Dergisi, 10(38), 11-31.

Auty, S. 1992. Consumer Choice and Segmentation in the Restaurant Industry. Service Industries Journal, 12(3), 324-339.

Bekar, A. \& Dönmez, F. 2016. Tüketicilerin Dışarıda Yemek Yeme Nedenlerine İlişkin Bir Değerlendirme. Social Sciences (NWSASOS), 11(1), 1-15.

Beldona, S., Moreo, A.P. \& Das Mundhra, G. 2010. The Role of Involvement And Variety-Seeking in Eating Out Behaviors. International Journal of Contemporary Hospitality Management, 22(3), 433-444.

Choi, J. \& Zhao, J. 2010. Factors Influencing Restaurant Selection in South Florida: Is Health Issue One of the Factors Influencing Consumers' Behavior When Selecting a Restaurant? Journal of Foodservice Business Research, 13(3), 237-251.

Chryssohoidis, G. M. \& Krystallis, A. 2005. Organic Consumers Personal Values Research: Testing and Validating The List of Values (LOV) Scale and Implementing a Value Based Segmentation Task. Food Quality and Preference, 16, 585-599.

Crompton, J. L. 1979. Motivations for pleasure vacation. Annals of Tourism Research, 6, 408-424.

Cullen, F. 2004. Factors Influencing Restaurant Selection in Dublin. Journal of Foodservice Research, 7(2), 53-85.

Dreezens, E., Martijn, C., Tenbult, P., Kok, G. \& de Vries, N. K. 2005. Food and Values: An Examination of Values Underlying Attitudes Toward Genetically Modified and Organically Grown Food Products. Appetite, 44(1), 115-122.

Ertürk, M. 2018. Müşterilerin Yiyecek İçecek İşletmeleri Tercihlerinde Etkili Olan Kriterler. Türk Turizm Araştırmaları Dergisi, 2(1), 85-107.

Gómez-Corona, C. \& Valentin, D. 2019. An Experiential Culture: A Review on User, Product, Drinking and Eating Experiences in Consumer Research. Food Research International, 115, 328-337.

Gürbüz, S. 2019. AMOS ile Yapısal Eşitlik Modellemesi Temel İlkeler ve Uygulamalı Analizler. Ankara: Seçkin Yayıncılık.

Gürbüz, S. \& Şahin, F. 2018. Sosyal Bilimlerde Araştırma Yöntemleri. Ankara: Seçkin Yayıncılık.

Hansen, T., Sørensen, M. I. \& Eriksen, M. L. R. 2018. How the Interplay Between Consumer Motivations and Values Influences Organic Food Identity and Behavior. Food Policy, 74, 39-52.

Harrington, R. J., Ottenbacher, M. C. \& Kendall, K. W. 2011. Fine-Dining Restaurant Selection: Direct and Moderating Effects of Customer Attributes. Journal of Foodservice Business Research, 14(3), 272-289.

Harrington, R. J., Ottenbacher, M. C. \& Way, K. 2013. QSR Choice: Key Restaurant Attributes and the Roles of Gender, Age and Dining Frequency. Journal of Quality Assurance in Hospitality \& Tourism, 14(1), 81-100.

Huber, F., Herrmann, A. \& Morgan, R. E. 2001. Gaining Competitive Advantage Through Customer Value Oriented Management. Journal of Consumer Marketing, 18(1), 41- 53.

Jang, Y., Kim, W. \& Bonn, M. 2011. Generation Y Consumers' Selection Attributes And Behavioral Intentions Concerning Green Restaurants. International Journal of Hospitality Management, 30(4), 803-811.

Jung, J., Sydnor, S., Lee, S. \& Almanza, B. 2015. A Conflict of Choice: How Consumers Choose Where To Go For Dinner. International Journal of Hospitality Management, 45, 88-98.

Kahraman, M. 2018. Ulusal Kültür Boyutlarının ve Kişisel Değerlerin Çalışan Mutluluğuna Etkisi: Türk ve Slovak Akademisyenler Üzerine Karşılaş̧ırmalı Bir Araştırma, Doktora Tezi, Burdur Mehmet Akif Ersoy Üniversitesi Sosyal Bilimler Enstitüsü, Burdur.

Karalar, R. \& Kirac1, H. 2010. Bireysel Değerlerin Sürdürülebilir Tüketim Davranışı Üzerindeki Etkisini Belirlemeye Yönelik Öğretmenler Üzerinde Bir Araştırma. Işsletme Araştırmaları Dergisi, 2(2), 79-106.

Kesic, T. \& Piri-Rajh, S. 2003. Market Segmentation on The Basis of Food Related Lifestyles of Croatian Families. British Food Journal, 105(3), 162-174.

Kim, E. \& Geistfeld, L. V. 2003. Consumer's Restaurant Choice Behavior and the Impact of Socio Economic and Demographic Factors. Journal of Foodservice Business Research, 6(1), 3-24. 
Kim, H. J., Lee, C., Kim, M. \& Ryu, K. 2011. Restaurant Healthy Food Quality, Perceived Value, And Revisit Intention: Testing a Moderating Role of Green Customers in South Korea. International CHRIE Conference-Refereed Track, July 292011.

Kim, J., Forsythe, S., Gu, Q. \& Moon, S. J. 2002. Cross-Cultural Consumer Values, Needs and Purchase Behavior. Journal of Consumer Marketing, 19(6), 481-502.

Kim, S., Ham, S., Moon, H., Chua, B. \& Han, H. 2019. Experience, Brand Prestige, Perceived Value (Functional, Hedonic, Social, and Financial), and Loyalty Among GROCERANT Customers. International Journal of Hospitality Management, 77, 169-177.

Kim, S., Lee, C. \& Klenosky, D. 2003. The Influence of Push And Pull Factors At Korean National Parks. Tourism Management, 24(2), 169-180.

Kivela, J. 1997. Restaurant Marketing: Selection and Segmentation in Hong Kong. International Journal of Contemporary Hospitality Management, 9(3), 116-123.

Kline, R. B. 2011. Principles and Practice of Structural Equation Modeling. New York: Guilford Publications.

Koo, L. C., Tao, F. K. C. \& Yeung, J. H. C. 1999. Preferential Segmentation of Restaurant Attributes Through Conjoint Analysis. International Journal of Contemporary Hospitality Management, 11(5), 242-253.

Korkmaz Devrani, T. 2010. Kişisel Değerlerin Kuramsal Yapısı ve Pazarlamadaki Uygulamalar. Eskişehir Osmangazi Üniversitesi İ̈BF Dergisi, 5(1), 49-70.

Krejcie, R. V. \& Morgan, D. W. 1970. Determining Sample Size for Research Activities, Educational and Psychological Measurement, 30(3), 607-610.

Kwun, D. J., Hwang, H. J. \& Kim, T. 2013. Eating-Out Motivations and Variety-Seeking Behavior: An Exploratory Approach on Loyalty Behavior. Journal of Hospitality Marketing \& Management, 22(3), 289-312.

Lee, P. Y., Lusk, K., Mirosa, M. \& Oey, I. 2014. The Role of Personal Values in Chinese Consumers' Food Consumption Decisions A Case Study of Healthy Drinks. Appetite, 73, 95-104.

Liu, P. \& Tse, E. C. Y. 2018. Exploring Factors On Customers' Restaurant Choice: An Analysis of Restaurant Attributes. British Food Journal, 120(10), 2289-2303.

MacKinnon, D. P., Lockwood, C. M., Hoffman, J. M., West, S. G. \& Sheets, V. 2002. A Comparison of Methods To Test Mediation and Other Intervening Variable Effects. Psychological Methods, 7(1), 83 104.

Medeiros, C.O. \& Salay, E. 2013. A Review of Food Service Selection Factors Important to the Consumer. Food and Public Health, 3(4), 176-190.

Murphy, K. R. \& Davidshofer, C. O. 1988. Psychological Testing: Principles and Applications. Englewood Cliffs, NJ: Prentice Hall.

Narine, T. \& Badrie, N. 2007. Influential Factors Affecting Food Choices of Consumers When Eating Outside the Household in Trinidad, West Indies. Journal of Food Products, 13(1), 19-29.

Nişancı, Z. N., Özdoğan, Y. \& Bölüktepe, F. E. 2018. Dışarıda Yemek Yeme Davranışının Nedenlerini Belirlemeye Yönelik İzmir İlinde Bir Araştırma. İzmir Katip Çelebi Üniversitesi İktisadi ve İdari Bilimler Fakültesi Dergisi, 1(1), 60-71.

Özdemir, B. 2010. Dışarıda Yemek Yeme Olgusu: Kuramsal Bir Model Önerisi. Anatolia: Turizm Araştırmaları Dergisi, 21(2), 218-232.

Özdemir, B. 2018. Yemek Deneyimi, K. Karamustafa (Ed.) Yiyecek ve İçecek Yönetimi kitabı içinde (sayfa 47-74). Detay Yayıncilik: Ankara.

Park, C. 2004. Efficient or enjoyable? Consumer Values of Eating-Out and Fast Food Restaurant Consumption in Korea. Hospitality Management, 23, 87-94.

Ponnam, A. \& Balaji, M. S. 2014. Matching Visitation-Motives and Restaurant Attributes in Casual Dining Restaurants. International Journal of Hospitality Management, 37, 47-57.

Ryu, K., Han, H. \& Jang, S. 2010. Relationships Among Hedonic and Utilitarian Values, Satisfaction and Behavioral Intentions in the Fast-casual Restaurant Industry. International Journal of Contemporary Hospitality Management, 22(3), 416-432.

Ryu, K., Lee, H. \& Kim, W. G. 2012. The Influence of The Quality of The Physical Environment, Food, And Service On Restaurant Image, Customer Perceived Value, Customer Satisfaction, And Behavioral Intentions. International Journal of Contemporary Hospitality Management, 24(2), 200-223.

Schwartz, S. H. 1992. Universals in The Content and Structure of Values. Theoretical Advances and Empirical Tests in 20 Countries. Advances in Experimental Social Psychology, 25, 1-65.

Schwartz, S. H. 2003. A Proposal For Measuring Value Orientations Across Nations. Questionnaire Package of the European Social Survey, 259-290.

Sweeney, J. C. \& Soutar, G. N. 2001. Consumer Perceived Value: The Development of A Multiple Item Scale. Journal of Retailing, 77, 203-220. 
Van Huy, L., Chi, M. T., Lobo, A., Nguyen, N. \& Long, H. P. 2019. Effective Segmentation of Organic Food Consumers in Vietnam Using Food-Related Lifestyles. Sustainability, 11, 1-16.

Vinson, D. E., Scott, J. E. \& Lamont, L. M. 1977. The Role of Personal Values in Marketing and Consumer Behavior. Journal of Marketing, 41, 44-50.

Wijaya, S., King, B., Nguyen, T. \& Morrison, A. 2013. International Visitor Dining Experiences: A Conceptual Framework. Journal of Hospitality and Tourism Management, 20, 34-42.

Y1lmaz, G. \& Gültekin, S. 2016. Consumers and Tourists' Restaurant Selections, Global Issues and Trends in Tourism kitabı içinde (sayfa 217-230). Sofia: St. Kliment Ohridski University Press.

Zeithaml, V. A. 1988. Consumer Perceptions of Price, Quality and Value: A Means-End Model and Synthesis of Evidence. Journal of Marketing, 52, 2-22. 